\title{
A Brief Analysis of Culture Aphasia in Higher English Teaching in China
}

\author{
Caiqiao Huo
}

\begin{abstract}
Culture is a result of the accumulation of human society; language is the important carrier of culture. Infiltration of Western culture and the widely use of English seriously hinder the globalization of the Chinese culture and it results in "cultural aphasia" phenomenon. After having studied foreign language for several years, many foreign language learners still cannot express Chinese traditional culture correctly in international communication. This is mainly due to the neglect of Chinese culture in the process of foreign language teaching. With the development of globalization, the communication between different cultures has become more and more frequent. It is necessary to pay more attention to the output of native language culture as well as the input of target language culture. As the main places of cultivating high-level talents in China, colleges and universities are focusing on how to change this phenomenon in the foreign language teaching reform. This paper begins with the introduction of "cultural aphasia" phenomenon in China, then analyzes the reasons, finally proposes suggestions and teaching strategies to overcome the culture aphasia in cross-cultural communication.
\end{abstract}

Keywords

Culture aphasia, teaching reform, higher education, cross-cultural communication

Culture is an important tradition heritage and a sign of the national cultural differences, and with the development of human society, it forms through the accumulation of ideology with the regional characteristics. Language is an important communication tool. It is the main carrier of human civilization that can be saved and inherited. There is an intimate relationship between language and culture, both influencing and restraining each other. On one hand, language reflects the culture of a nation, it is the power for culture to survive; on the other hand, culture is spread through language, especially in the cross-cultural communication. New words and expressions in language restrict the development of culture. As China's comprehensive national strength has increased, it triggers a boom about learning Chinese traditional culture. More and more Western scholars even civilians join in learning it. How to realize the goal of introducing Chinese traditional culture to the world? It has become a new challenge for the Chinese scholars.

“Aphasia” originally refers to partial or total loss of ability to speak or understand spoken language, caused by damage to the brain (Hornby and Lee 1997). In 2000, a scholar named Cong Cong brought aphasia from the medical field into the foreign language teaching research for the first time. He pointed out that many Chinese scholars who engaged in foreign

aBaoding University, China

Correspondent Author:

Caiqiao Huo, Foreign Languge Department, Baoding Uniersity, Baoding, China

E-mail: 150095119@qq.com 
language teaching had difficulty in explaining Chinese traditional culture when they communicated with foreigners. He also proposed that national cultural education should be introduced in foreign language teaching (Cong Cong 2000). "Cultural aphasia” phenomenon not only hinders cross-cultural communication, but also restricts the transmission of local traditional culture. Therefore, in order to realize the goal of introducing Chinese culture to the world, it is necessary to find out the causes of "cultural aphasia" phenomenon and have them solved.

Universiries and institutions are the main places to cultivate high-level, high-quality talents. Foreign language teaching is the key to improving their ability, no matter for English majors or non-English majors. In cross-cultural communication, advanced talents play a role as cultural exchange ambassadors, so how to make our culture better and further? We should integrate the local culture into the foreign language teaching .

This paper introduces "cultural aphasia" phenomenon in China firstly, then analyzes the reasons, at last, some suggestions are provided.

\section{REASONS OF CULTURE APHASIA PHENOMENON}

\section{Historical Reason}

Since modern times, Western culture occupies a dominant position in the world, and it is the symbol of the advanced culture; on the contrary, Chinese culture is the representative of backward culture. In the exchange between the East and the West, Chinese culture is largely influenced by Western culture and even loses its voice on the world cultural exchange stage.

\section{Economic Reason}

Powerful economic strength is a strong support in the development of culture. Some foreign countries carry out a policy of cultural conquest around the world by selling its life style and ideology, while local culture is regarded as vulgar. Thus, cultural aphasia phenomenon is inevitable occurred.

\section{Political Reason}

Political reason mainly refers to the policy orientation. In 2007, the Ministry of Education issued the College English Curriculum Requirements, it stipulates that the main contents of college English teaching should focus on English language knowledge and students' application skills, cross-cultural communication and learning strategies (Zhao 2011). Though the cross-cultural communication is mentioned, there is no requirement for studying Chinese culture. The mistaken orientation of the teaching requirements makes a vast of teachers and students believe that foreign language teaching in colleges and universities is the import of foreign culture not native culture, so they pay more attention to guiding students to learn Western customs, habits, values, etc., ignoring the importance of local culture input. In addition, we use a lot of foreign raw materials in the arrangement of contents in textbook (Table 1 shows the contents of textbooks used by freshman and graduate respectively), and few of the contents are about Chinese traditional culture. Although it may help to improve students' thinking ability, a lack of vocabulary to express local culture has been discovered.

\section{Partial Understanding of Cross-Cultural Communication}

For a long time, the foreign language teaching practice simply attaches great importance to the input of the target language and its culture, ignoring the output of native language and Chinese culture, so it will form a "one-sided" culture communication, combined with a lack of confidence in non-English speaking countries. They just follow Western culture blindly, let alone spread out the essence of local culture (Zhao 2011). 
Table 1. Proportion of the Two Culture Information Input in the Textbook

\begin{tabular}{llllllllll}
\hline Names & $\begin{array}{l}\text { Total } \\
\text { text }\end{array}$ & $\begin{array}{l}\text { Western } \\
\text { culture }\end{array}$ & $\begin{array}{l}\text { Proportion } \\
(\%)\end{array}$ & $\begin{array}{l}\text { Chinese } \\
\text { culture }\end{array}$ & $\begin{array}{l}\text { Proportion } \\
(\%)\end{array}$ & $\begin{array}{l}\text { Culture } \\
\text { comparison }\end{array}$ & $\begin{array}{l}\text { Proportion } \\
(\%)\end{array}$ & Others & $\begin{array}{l}\text { Proportion } \\
(\%)\end{array}$ \\
\hline $\begin{array}{l}\text { English } \\
\begin{array}{l}\text { Advanced } \\
\text { English }\end{array}\end{array}$ & 40 & 35 & 87.5 & 0 & - & 5 & 12.5 & 0 & - \\
\hline
\end{tabular}

\section{EMPIRICAL METHOD}

Baoding Uniersity is one of the key universities in Hebei Province. Its discipline advantage is liberal arts, such as literature, philosophy, especially in foreign language study. It has made excellent achievements. Taking this university as an example, the author makes relevant research and analysis with questionnaire method among undergraduates, including English majors and non-English majors. There are 100 students involved in this study, including 60 English majors and 40 non-English majors. There are totally 100 copies handed out, with 98 effective questionnaires being taken back, the recovery rate is $98 \%$.

\section{The Situation of Students to Grasp Chinese Traditional Culture}

There are 50 topics in the questionnaire about Chinese traditional culture and it covers all aspects of traditional culture as much as possible. Two points for each question if right, otherwise zero. From questionnaire score results, we may reach the conclusion that non-English major undergraduate students for low-scoring, and English major graduate serves the highest. The results are shown in Table 2.

\section{Chinese Traditional Culture Curriculum and the Status of the Classroom Teaching}

In the questionnaire, students are required to select the most closely related species about Chinese traditional culture (at least five courses) and write down, in addition, whether there is a teacher to guide in learning Chinese traditional culture or its English expression and whether they are able to learn about Chinese traditional culture in the teaching textbook. After analysis, the author found that only the English majors said that the teacher would introduce some traditional Chinese culture during the process of foreign language teaching for upper grade students. The non-English majors are the least to getting assess to traditional Chinese culture. Figure 1, Figure 2, and Figure 3 are shown in the following chart.

\section{Students' Attitude to Chinese Culture in English Education}

There are five questions in questionnaire, inquiring students' attitude about whether Chinese traditional culture should be taught in English teaching. More than $60 \%$ of the students think that it is very necessary; only $5 \%$ of the students think that it is unnecessary, as shown in Figure 4. This suggests that students are eager to learn the foreign expressions of Chinese traditional culture, but due to their lack of knowledge, it is unsatisfactory for them to grasp the expressions of Chinese traditional culture.

\section{SUGGESTIONS}

Because the "cultural aphasia” phenomenon has occured, more and more scholars put forward different opinions and suggestions. It may be said that "hundred flowers blooming and hundred schools contending”, and each one has his own point of view. But on the whole, the focus of the debate is how to integrate Chinese native culture into the teaching of foreign language teaching. 
Table 2. The Situation of English Major and Non-English Major Students About Chinese Traditional Culture

\begin{tabular}{llllll}
\hline $\begin{array}{l}\text { Students } \\
\text { category }\end{array}$ & $\begin{array}{l}\text { English major } \\
\text { undergraduates }\end{array}$ & $\begin{array}{l}\text { English major } \\
\text { graduate students }\end{array}$ & $\begin{array}{l}\text { Non-English major } \\
\text { undergraduates }\end{array}$ & $\begin{array}{l}\text { Non-English major } \\
\text { graduate students }\end{array}$ & The average \\
\hline $\begin{array}{l}\text { Scoring rate } \\
(\%)\end{array}$ & 72.5 & 78.9 & 60.7 & 68.9 & 70.25 \\
\hline
\end{tabular}

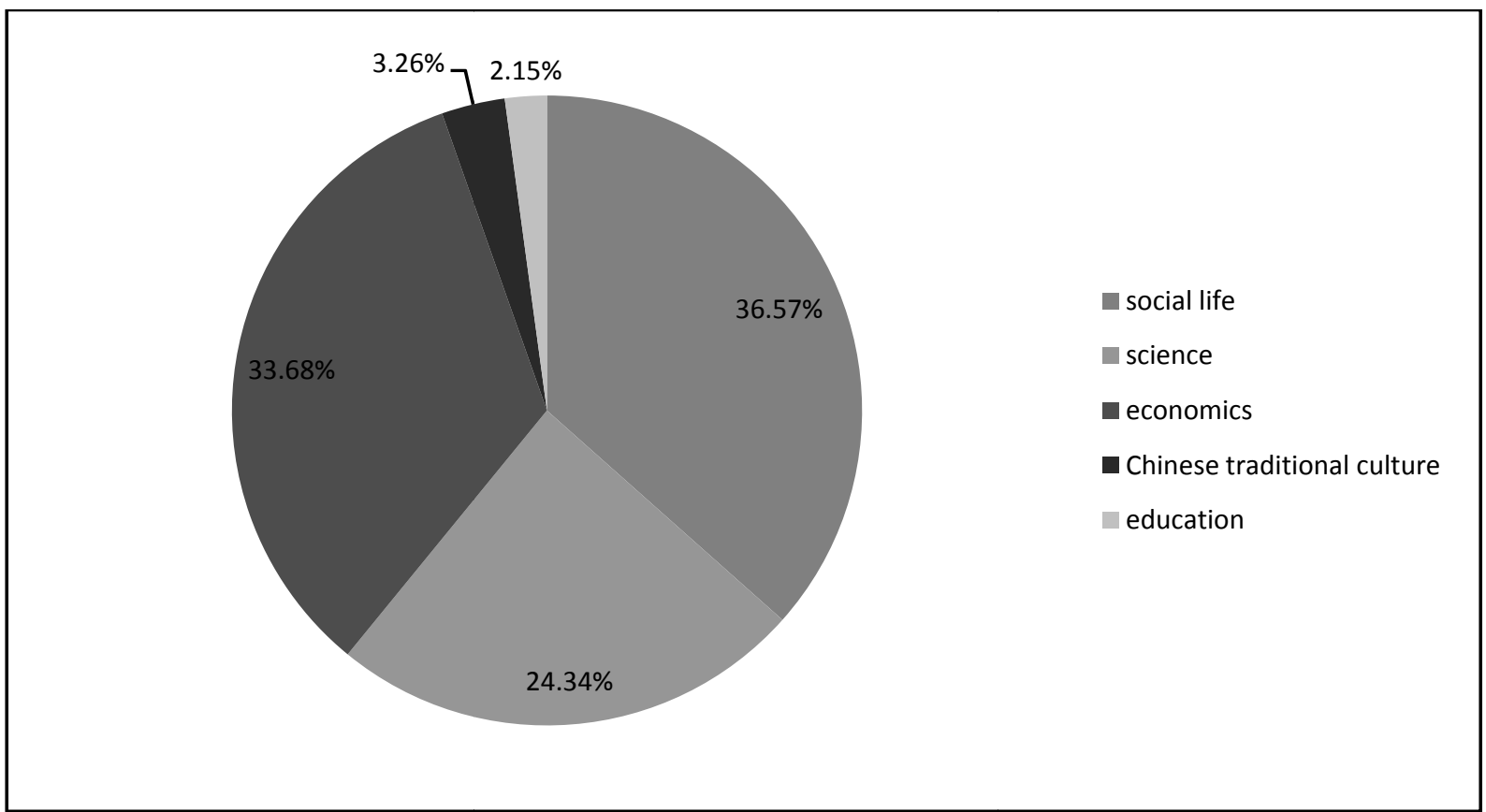

Figure 1. Non-English Major Teaching Textbook Form.

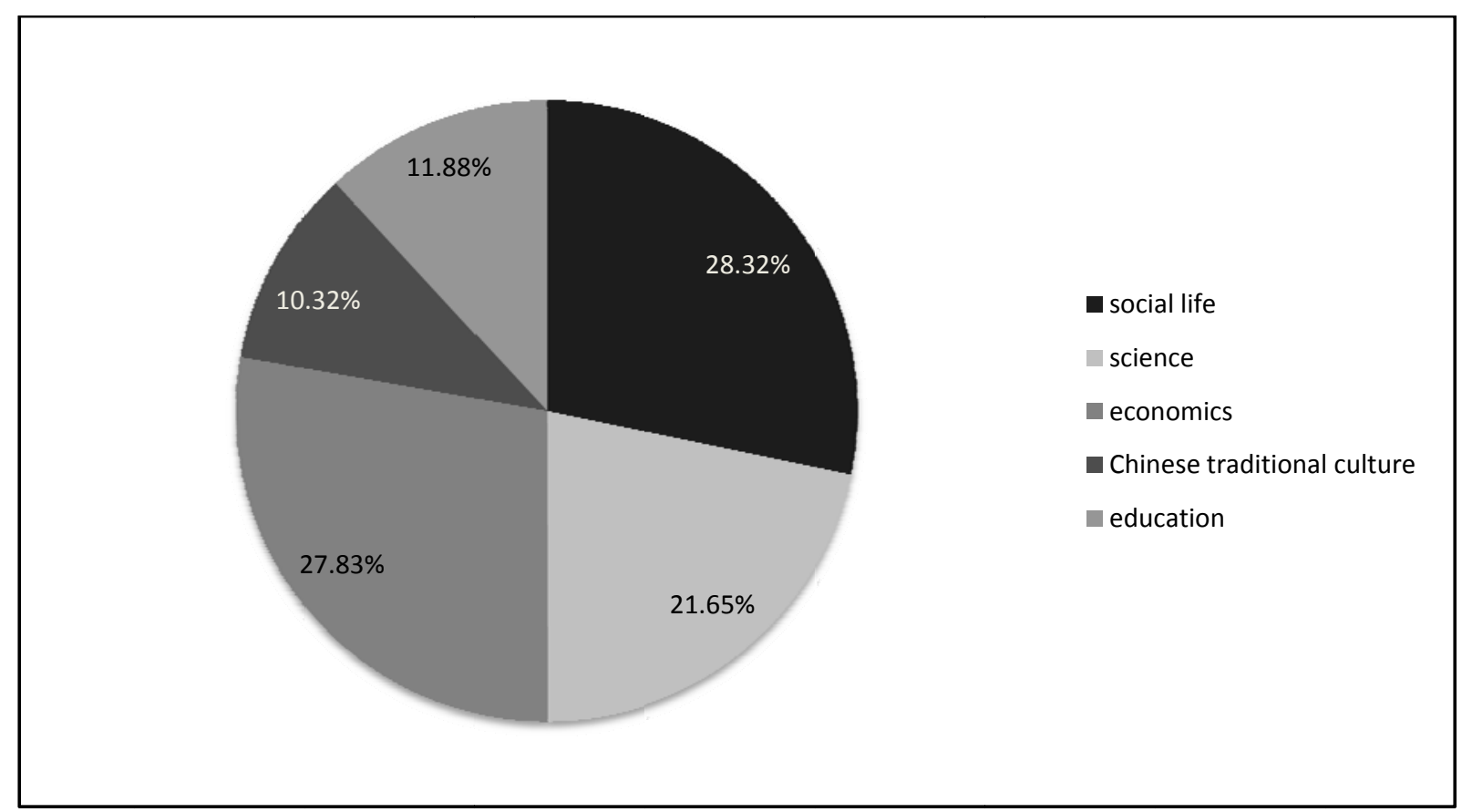

Figure 2. English Major Teaching Material Form. 


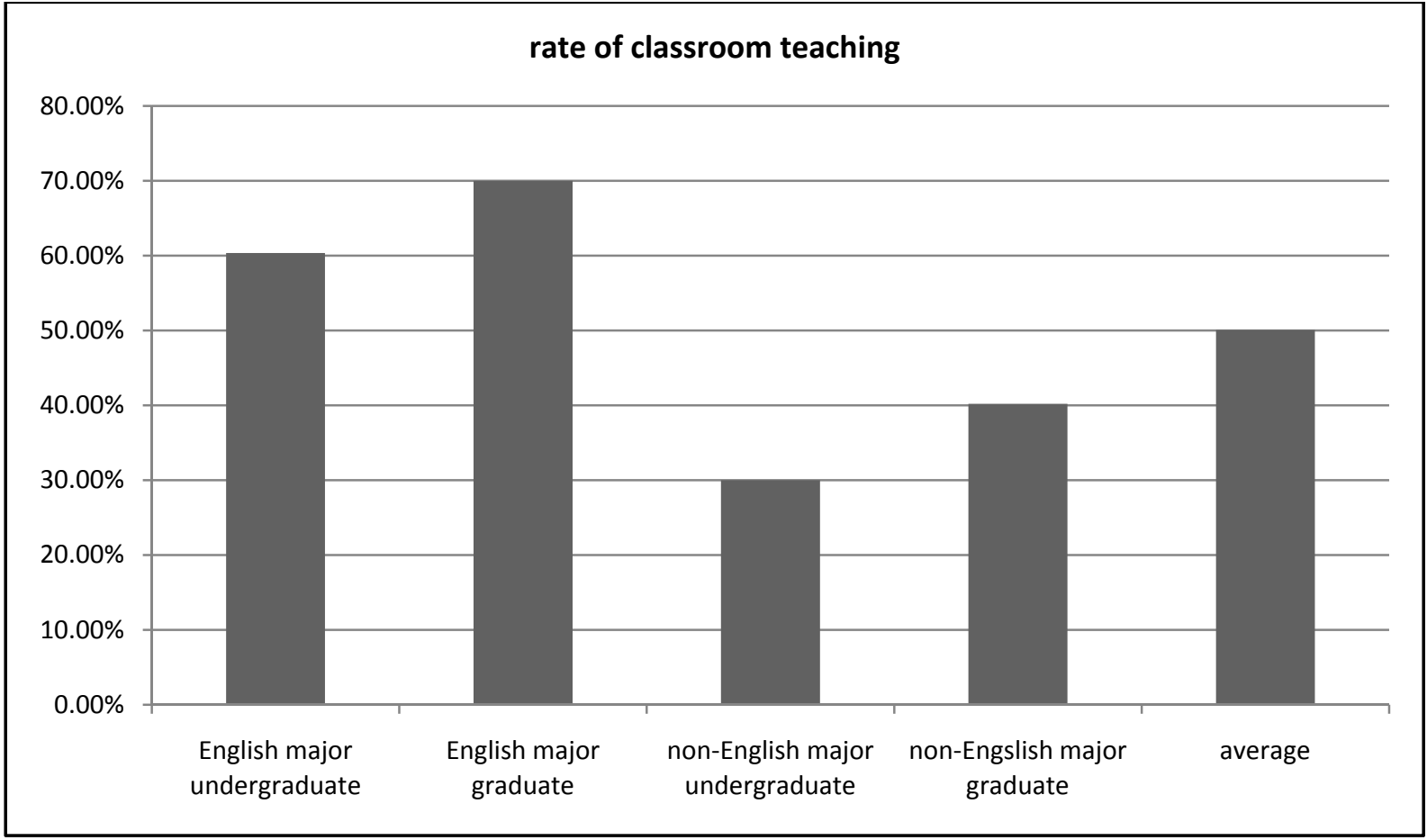

Figure 3. Foreign Language Expression Rate of Chinese Traditional Culture in Class.

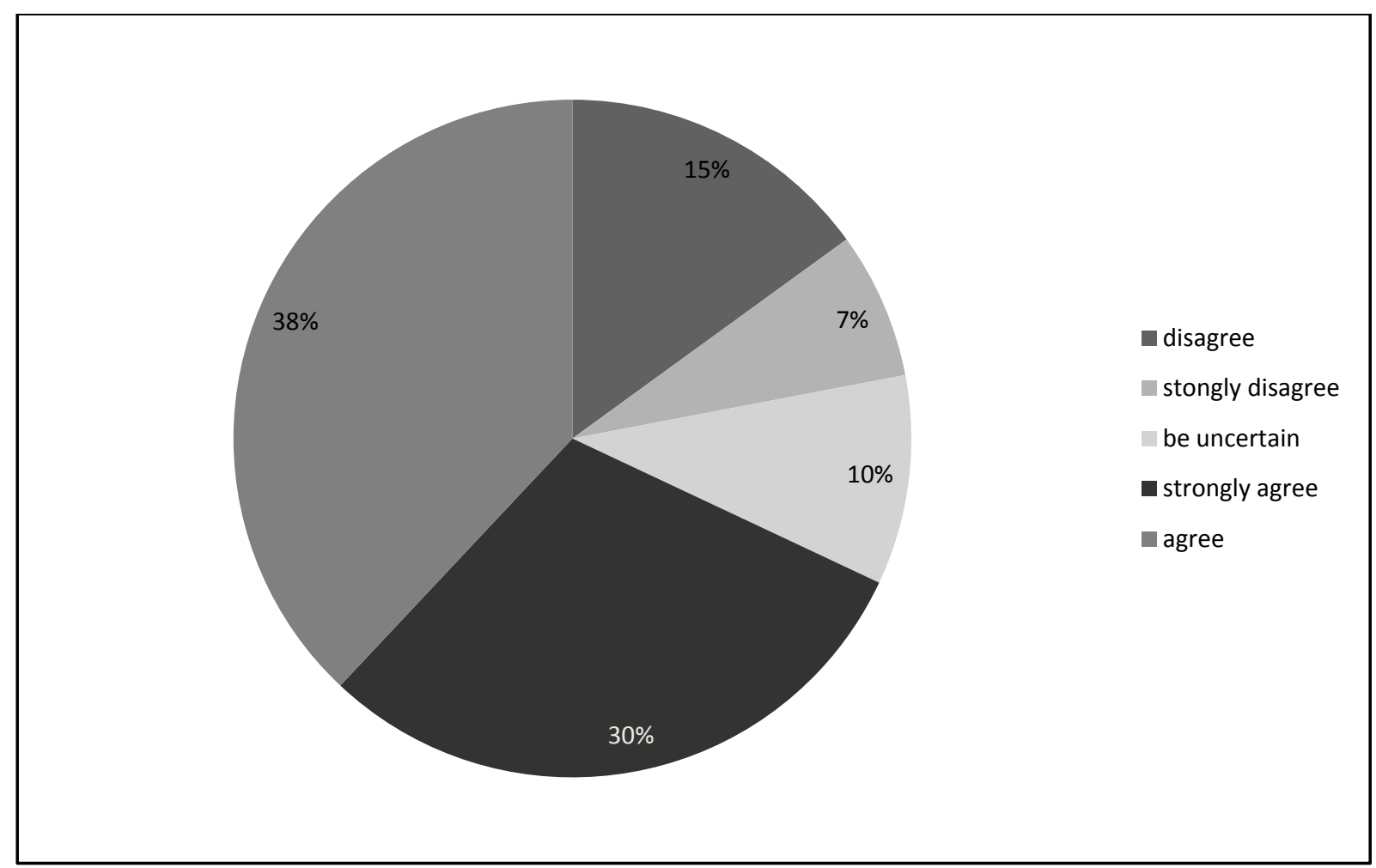

Figure 4. Whether Traditional Chinese Cultural Knowledge Should Be Taught in English Teaching. 


\section{Improvement of the Teaching Quality for the Foreign Language Teachers}

Foreign language teachers are the main forces of foreign language teaching in colleges and universities, playing an important role in spreading Chinese culture. On one hand, foreign language teachers are professionally trained in the field of foreign language, they have a higher capacity in terms of understanding the Western culture, so they should take more responsibility in spreading Chinese culture; on the other hand, as foreign language teachers in colleges and universities, it is necessary for them to instruct students to learn about the Chinese culture, in order to enhance the global spreading of Chinese culture.

The foreign language teachers' understanding of the traditional chinese culture and their teaching idea affect the student's learning effect, so it is imperative to improve their knowledge of the traditional culture. First, teachers should abandon the traditional teaching concept, fully aware of the importance and urgency of native culture in foreign language teaching. They should improve themselves and the ability to express Chinese culture in English consciously. They also should accumulate the English expression of Chinese culture through reading books on traditional culture, search for information on the internet, participate in academic exchanges regularly, and learn more in other different ways. They should aim to extend their knowledge and improve their communication skills with more practice.

\section{The Editing of the Foreign Language Textbook}

Although there are a lot of foreign language textbook on the market currently, a common phenomenon is that the selected articles originate from foreign periodicals or books and so on. Few of them are related to Chinese traditional culture. Students just blindly pursue how to comply with the foreign language thinking style and make the expression more authentic, but as to how to use a foreign language to express Chinese traditional culture, they have a lot of difficulties. So "cultural aphasia" phenomenon is unavoidable. Therefore, the arrangement of the contents in teaching materials should consciously increase the contents about introduction of Chinese traditional culture in foreign language. This not only can make students learn authentic language expressions, but also can guide students to set up the correct cultural values, mobilize their interest in initiative to explore Chinese traditional culture.

\section{Cultivation of the Students' Sense of National Pride in Intercultural Communication}

China is a country with a long history. Chinese culture is vast and profound. Cultivating the students' sense of national pride and enhancing their national self-confidence are necessary to decrease the "cultural aphasia" phenomenon. Intercultural communication is an important way for Chinese culture to "bring in" and "go out". We can learn foreign advanced culture as well as introduce Chinese outstanding culture to people all over the world. At last, we can understand the differences between cultures and communicate better. Nowadays, China is playing a more and more important role in the international arena, more and more Western scholars are keen to study Chinese traditional culture, so a successful intercultural communication is not only about the input of foreign cultural, but also about the output of local culture.

\section{CONCLUSIONS}

Integrating native culture teaching into foreign language teaching should be emphasized in higher foreign language education. Against the background of globalization, the communication between various cultures has become closer and more frequent, and two-way communication is necessary for people to 
achieve a win-win result. So, aiming at solving the problem of Chinese culture aphasia, foreign language teachers should train the students to remember more words to express their native culture with the target language, encourage the students to spread their native culture and become successful in the future cross-cultural communication.

\section{Funding}

This paper is supported by Baoding University Foundation (No. 2014J04).

\section{References}

Cong Cong. 2000. "Chinese Culture Aphasia: Limitations of English Education in China.” Guangming Newspaper, October 19, C01.

Hornby, A. S. and B. D. Lee. 1997. Oxford Advanced Learner's English-Chinese Dictionary. Beijing: The Commercial Press.

Hua, Y. 2010. "Reflecting on Foreign Culture Teaching From Aphasia of Chinese Culture.” Journal of Gansu Lianhe University (Social Sciences) 26(3):108-111.

Jia, Y. X. 2006. International Communication. Shanghai:
Shanghai Foreign Language Education Press.

Kramsch, C. 1998. Language and Culture. Oxford: Oxford University Press.

Luo, S. Q. and X. Li. 2009. "On Aphasia of Chinese Culture in English Teaching." Journal of Sichuan College of Education 25(6):84-86.

Marilla, R. and Y. H. Ji. 2012. A Practical Course in International Communication. Shanghai: Shanghai Foreign Language Education Press.

Xiao, L. F., D. Xiao, L. Li, and Y. W. Song. 2010. “A Study of the 'Chinese Culture Aphasia' in Present English Education in Chinese Higher Education.” Foreign Language Learning Theory and Practice 1:39-47.

Zhao, Y. 2011. "Lack of Local Culture in Cultural Aphasia Phenomenon and Countermeasure Research." Forward Position 24:192-193.

Zhou, X. L. 2010. "Study on Cultural Aphasia in College English Teaching in China.” Journal of Language and Literature Studies 5:152-153.

\section{Bio}

Caiqiao Huo, M.A., lecturer, Foreign Language Department, Baoding University; research fields: foreign languge teaching, American and British literature, American and British Culture, and cross-cultural communication. 